\title{
Association of mineral composition of neonatal intravenous feeding solutions and metabolic bone disease of prematurity
}

\author{
P MACMAHON,${ }^{*}$ M E BLAIR, ${ }^{*}$ P TREWEEKE, $\dagger$ AND I Z KOVAR* \\ Departments of *Paediatrics and †Radiology, Charing Cross Hospital, London
}

\begin{abstract}
SUMMARY To assess the effects of increasing the mineral content of parenteral nutrition solutions on the biochemical and radiological indicators of metabolic bone disease of prematurity 27 neonates who required parenteral nutrition were sequentially allocated to receive either a standard solution (group 1) or one with an increased mineral content (group 2). The 13 patients in group 1 received $0.68 \mathrm{mmol} / \mathrm{kg} /$ day of calcium and $0.61 \mathrm{mmol} / \mathrm{kg} / \mathrm{day}$ of phosphorus, and the 14 in group 2 received 1.25 and $1.20 \mathrm{mmol} / \mathrm{kg} /$ day, respectively. The two groups did not differ significantly in the severity of their illness measured by birth weight, gestational age, duration of parenteral nutrition or ventilation, or the amount of supplementary oxygen required. In patients in group 2 the median plasma phosphate concentration was higher, the plasma alkaline phosphatase activity was lower, and there was less radiological evidence of rickets. There were no complications caused by excess calcium and phosphorus, and the rate of growth was similar in both groups. We conclude that an increased mineral content in parenteral nutrition solutions reduces the severity of metabolic bone disease in sick infants who require this form of nutrition.
\end{abstract}

Metabolic bone disease is common in premature infants whether they are fed enterally ${ }^{1}$ or parenterally. ${ }^{2}$ Deficiency in the mineral substrate is thought to be an important aetiological factor, ${ }^{3}$ though increasing the intake of calcium and phosphorus in enterally fed infants failed to reduce the incidence of rickets. ${ }^{4}$ In utero accretion of calcium occurs at about $2.75-3.25 \mathrm{mmol} / \mathrm{kg} /$ day, and phosphorus at about $2 \cdot 1-2.6 \mathrm{mmol} / \mathrm{kg} /$ day $^{5}$; conventional intravenous feeding solutions cannot deliver these minerals at these rates without making them insoluble. ${ }^{6}$ Alternating solutions with either a high calcium or phosphorus concentration has been tried to overcome this problem, ${ }^{7}$ but this increases the difficulty of feeding, and a fluctuating intake is not physiological.

The amount of calcium and phosphorus that can be held in solution without precipitation is decreased if the amino acid concentration is decreased. ${ }^{8}$ Our standard parental nutrition solution normally delivers calcium and phosphorus at a rate of $0.6-1.0$ and $0.7 \mathrm{mmol} / \mathrm{kg} /$ day, respectively. If higher rates are attempted, precipitation occurs if the intake of amino acid is reduced. In vitro studies have, however, shown that the intake of calcium and phosphorus can be increased to as much as 2.0 and $1.7 \mathrm{mmol} / \mathrm{kg} /$ day, respectively, without precipitation if the intake of amino acid (using Vamin-9-glucose, KabiVitrum) is maintained at $50 \mathrm{ml} / \mathrm{kg} / \mathrm{day}$ (P MacMahon, et al, unpublished observations). We used this to formulate a second parenteral nutrition solution with an increased calcium and phosphorus content without altering the amino acid content. The modified solution with extra calcium and phosphorus was then compared with our previous standard in a controlled trial designed to assess the effects of the increased mineral content of the parenteral nutrition solution on the biochemical and radiological indicators of metabolic bone disease of prematurity.

\section{Patients and methods}

Between July 1985 and October 1986 every infant admitted to the neonatal intensive care unit at this hospital who required parenteral nutrition was sequentially allocated to one of two groups that received either our standard solution (group 1) or one with an increased mineral content (group 2). The prescription and formulation was aided by a 
modification of a previously published computer protocol from this unit. ${ }^{9}$ The two formulas differed only in their calcium and phosphorus content. Daily intakes of calcium and phosphorus were altered according to the plasma concentration, provided that the total fluid and amino acid intake were such that precipitation would not occur (table 1). The intake of phosphorus in group 1 was not influenced by the plasma concentration, but was limited to $0 \cdot 3$ $\mathrm{mmol} / \mathrm{kg} / \mathrm{day}$ if the intake of calcium was more than $1 \mathrm{mmol} / \mathrm{kg} /$ day, or if the intake of fluid was less than $120 \mathrm{ml} / \mathrm{kg} /$ day, or if the intake of Vamin was less than $30 \mathrm{ml} / \mathrm{kg} /$ day. ${ }^{7} 8$

Criteria for inclusion in the study were that at least $75 \%$ of the volume of fluid was given intravenously, and that parenteral nutrition was required for at least 14 days. The prescription of parenteral feeding was by standard clinical criteria. When enteral feeding was possible the mother's own expressed breast milk was used in preference; if not, a proprietary preterm formula was used (Prematalac, Cow and Gate or Osterprem, Farley).

Calcium in the parenteral nutrition solution was supplied as $10 \%$ calcium gluconate $(2.2 \mathrm{mmol} /$ $10 \mathrm{ml}$ ), in the trace element preparation (Pedel, KabiVitrum $1.5 \mathrm{mmol} / 10 \mathrm{ml}$ ) and in the amino acid preparation (Vamin-9-glucose, KabiVitrum, 0.25 $\mathrm{mmol} / 100 \mathrm{ml}$ ). Phosphorus was supplied as $8.7 \%$ potassium phosphate $(5 \mathrm{mmol} / 10 \mathrm{ml})$ and in the trace element preparation (Pedel, KabiVitrum, 0.75 $\mathrm{mmol} / 10 \mathrm{ml}$ ). Particular attention was paid to the sequence of additions during the formulation to avoid precipitation. The phosphorus salt was the first additive to the amino acid/dextrose mixture, and any calcium salts were added last. ${ }^{8}$ The solutions were refrigerated until required. The amount of each solution infused was recorded and from this the

Table 1 Amounts of calcium and phosphorus prescribed depending on plasma concentration

\begin{tabular}{|c|c|c|c|}
\hline & \multirow{2}{*}{$\begin{array}{l}\text { Plasma } \\
\text { concentration } \\
\text { (mmol/l) }\end{array}$} & \multicolumn{2}{|c|}{ Intake ( $\mathrm{mmol} / \mathrm{kg} /$ day $)$} \\
\hline & & Group 1 & Group 2 \\
\hline \multirow[t]{7}{*}{ Calcium: } & $>2 \cdot 8$ & 0 & 0 \\
\hline & $2 \cdot 61-2 \cdot 8$ & 0 & $0 \cdot 6$ \\
\hline & $2 \cdot 41-2 \cdot 6$ & 0.6 & 1.0 \\
\hline & $2 \cdot 21-2 \cdot 4$ & 0.6 & 1.5 \\
\hline & $2 \cdot 01-2 \cdot 2$ & 1.0 & $2 \cdot 0$ \\
\hline & $1 \cdot 5-2 \cdot 0$ & 1.5 & $2 \cdot 0$ \\
\hline & $<1 \cdot 5$ & $2 \cdot 0$ & $2 \cdot 0$ \\
\hline \multirow[t]{3}{*}{ Phosphorus: } & $>2 \cdot 0$ & & $0 \cdot 3^{*}$ \\
\hline & $1 \cdot 51-2 \cdot 0$ & 0.7 & 0.7 \\
\hline & $\leqslant 1 \cdot 5$ & & $1 \cdot 7 \dagger$ \\
\hline
\end{tabular}

${ }^{*}$ Minimum intake if estimations of trace elements requested. †Limited to 1.2 if intake of Vamin $=40 \mathrm{ml} / \mathrm{kg} /$ day and to 0.7 if intake of Vamin $<40 \mathrm{ml} / \mathrm{kg} /$ day. amount of calcium and phosphorus actually delivered was calculated.

The mineral content of expressed breast milk was assumed to be $7.0 \mathrm{mmol} / \mathrm{l}$ of calcium and $4.8 \mathrm{mmol} / \mathrm{l}$ of phosphorus with an average absorption rate of 34 and $86 \%$ respectively. ${ }^{10}$ The mineral content of any proprietary milk used was calculated from the manufacturer's data sheet and the percentage absorption of calcium and phosphorus was assumed to be 42 and 82.5 , respectively. ${ }^{10}$ From these data the amount of calcium and phosphorus absorbed from any enteral feeds was calculated.

The plasma concentration of calcium was measured 48 hourly, or more frequently if clinically indicated. The plasma concentration of phosphate and the alkaline phosphatase activity were measured at least weekly. These assays were done on an American Parallel Monitor using approved methods. Standardised radiographs of the wrists were taken every two weeks, and subsequently reviewed by a single observer who was unaware of which group the patient was in (PT). They were each given a radiological score using the method of Koo et al in which the classical radiographic changes of serious rickets equalled grade $2 .{ }^{11}$

Parenteral nutrition was normally infused through a silicone catheter (Vygon) inserted percutaneously, the tip of which was placed in a large central vein (axillary vein, superior or inferior vena cava) to make it easier to give high dextrose concentrations (greater than $10 \%$ ). When this was not technically possible (and also during episodes of suspected septicaemia) a peripheral vein was used. In infants who were particularly unstable and in whom an umbilical arterial catheter was already in situ, this was used.

Measurements of weight, head circumference, and length were recorded weekly using an electronic scale, graduated tape measure, and measuring board respectively.

Statistical analysis of the data was by the Statistical Package for the Social Sciences (SPSS-X) computer program using Student's $t$ test to assess significance of differences for parametric data, and the Mann-Whitney U test for non-parametric data (including the radiological scores). The study was approved by the hospital ethics committee.

\section{Results}

Twenty seven infants (13 in group 1 and 14 in group 2) were enrolled in the study. At birth there were no significant differences between the groups for gestational age, birth weight, or sex. Subsequently there were no differences between the groups in their severity of illness as measured by the durations of 
parenteral nutrition, ventilator support, or the amount of supplementary oxygen required. Parenteral nutrition was usually fully established after seven days, and only the results obtained after this time were analysed. There were no differences between the groups in the daily intravenous intake of protein, fat, or carbohydrate, and the energy and mineral contents of the small quantities of enteral feeds (table 2).

The intakes of copper $(0 \cdot 3 \mu \mathrm{mol} / \mathrm{kg} /$ day supplied in Pedel, KabiVitrum), zinc $(0 \cdot 6-\mu \mathrm{mol} / \mathrm{kg} /$ day also supplied in Pedel, KabiVitrum), and vitamin C (3.4 $\mathrm{mg} / \mathrm{kg}$ /day of sodium ascorbate supplied in Solivito, KabiVitrum) were identical in both groups.

The modified parenteral nutrition regimen achieved its primary objective of delivering an increased amount of mineral substrate to the 14 infants in group 2. Group 1 received $0.68 \mathrm{mmol} / \mathrm{kg} /$ day of calcium and $0.61 \mathrm{mmol} / \mathrm{kg} /$ day of phosphorus whereas group 2 received 1.25 and 1.20 , respectively (table 2).

The plasma calcium concentration remained normal throughout the study with the mean weekly value remaining within the range $2.3-2.5 \mathrm{mmol} / \mathrm{l}$ in both groups. In group 1 the plasma phosphate concentration was lower, the plasma alkaline phosphatase activity was higher and the radiological scores for rickets were higher while the infants remained on parenteral nutrition (figure). The only three infants to develop classical radiographic changes of rickets (grade 2) were all in group 1.

There was no difference in the rate of growth between the groups measured by the weekly mean

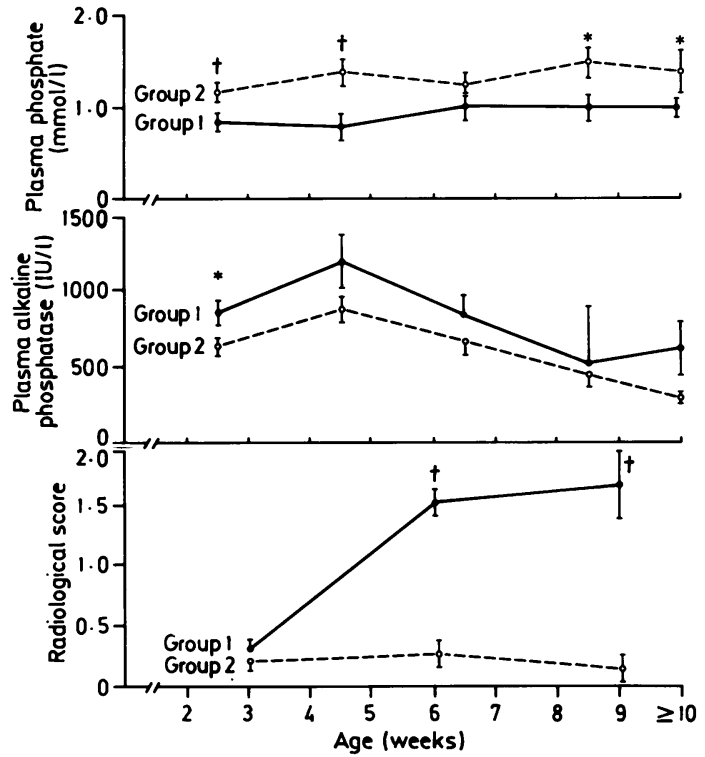

Figure Plasma phosphate concentration, alkaline phosphatase activity, and radiological score with increasing age. Vertical bars are mean $(S E M) ; *^{*}=p$ value $\leqslant 0 \cdot 1$ and $\dagger=p$ value $\leqslant 0.05$ (Mann-Whitney U test).

percentage increase in weight, length, or head circumference. Comparing group 1 with group 2 after six weeks on parenteral nutrition the weight gain was $53 \cdot 3 \%$ compared with $45 \cdot 2 \%(\mathrm{p}=0.55)$, the increase in length was $8.7 \%$ compared with $13.4 \%$

Table 2 Clinical characteristics and mineral intakes of infants studied expressed as median (range)

\begin{tabular}{|c|c|c|c|}
\hline & Group 1 & Group 2 & p Value \\
\hline Birth weight $(\mathrm{g})$ & $960(580-1760)$ & $830(590-1495)$ & NS \\
\hline Gestational age (weeks) & $28(25-33)$ & $26(24-41)$ & NS \\
\hline Male:female ratio & $7: 6$ & $8: 6$ & NS \\
\hline \multicolumn{4}{|l|}{ Duration of: } \\
\hline Parenteral nutrition (days) & $48(14-199)$ & $56(14-77)$ & NS \\
\hline $\begin{array}{l}\text { Intermittent positive pressure ventilation } \\
\text { (days) }\end{array}$ & $48(0-102)$ & $40(2-83)$ & NS \\
\hline Supplementary oxygen (days) & $18(0-51)$ & $16(0-75)$ & NS \\
\hline \multicolumn{4}{|l|}{ Parenteral intake: } \\
\hline Energy $(\mathrm{MJ} / \mathrm{kg} /$ day $)$ & $0 \cdot 360(0 \cdot 176-0 \cdot 594)$ & $0 \cdot 360(0 \cdot 142-0 \cdot 523)$ & NS \\
\hline Protein $(\mathrm{g} / \mathrm{kg} /$ day) & $3.43(1 \cdot 05-4 \cdot 2)$ & $3 \cdot 49(0 \cdot 2-4 \cdot 2)$ & NS \\
\hline Fat $(\mathrm{g} / \mathrm{kg} /$ day $)$ & $2 \cdot 2(0 \cdot 4)$ & $2 \cdot 1(0-4 \cdot 1)$ & NS \\
\hline Dextrose (g/kg/day) & $13 \cdot 5(6 \cdot 8-23)$ & $13 \cdot 2(3 \cdot 1-20 \cdot 1)$ & NS \\
\hline \multicolumn{4}{|l|}{ Enteral intake: } \\
\hline Energy $(\mathrm{MJ} / \mathrm{kg} / \mathrm{day})$ & $0.004(0-0 \cdot 146)$ & $0.008(0-0 \cdot 155)$ & NS \\
\hline Calcium (mmol/kg/day) & $0(0-0 \cdot 2)$ & $0.02(0-0.4)$ & NS \\
\hline Phosphorus (mmol/kg/day) & $0(0-0 \cdot 4)$ & $0.02(0-0 \cdot 81)$ & NS \\
\hline \multicolumn{4}{|l|}{ Total mineral intake: } \\
\hline Calcium (mmol/kg/day) & $0.68(0 \cdot 32-1 \cdot 05)$ & $1.25(0 \cdot 29-1 \cdot 84)$ & $<0 \cdot 001$ \\
\hline Phosphorus $(\mathrm{mmol} / \mathrm{kg} / \mathrm{day})$ & $0.61(0 \cdot 16-0.98)$ & $1.20(0.39-1.74)$ & $<0.001$ \\
\hline
\end{tabular}


$(p=0.09)$, and the increase in head circumference was $10 \cdot 3 \%$ compared with $15 \%(p=0 \cdot 16)$.

\section{Discussion}

We have shown that it is possible to increase significantly the calcium and phosphorus content of intravenous feeding solutions prescribed for preterm neonates. Rickets of prematurity is a recognised complication of parenteral nutrition in these babies $^{2}$; and mineral deficiency is thought to be an important factor in the aetiology of metabolic bone disease in infants ${ }^{3}$; it is well recognised in association with prolonged parenteral nutrition. ${ }^{2}{ }^{12}$ If calcium and phosphorus are added to conventional parenteral nutrition solutions in the concentrations necessary to maintain normal transplacental transfer and accretion, ${ }^{5}$ precipitation of calcium and phosphate crystals usually occurs. ${ }^{6}$ Because of this, most regimens limit the delivery of these minerals to less than $1 \mathrm{mmol} / \mathrm{kg} /$ day of each.

The factors that increase the likelihood of precipitation of calcium and phosphorus in parenteral nutrition solutions include high molar concentrations, high $\mathrm{pH}$ of the solution, low concentrations of amino acid, high temperature, prolonged standing times, adding the calcium salts either first or before the final dilution, and the use of the chloride salt as a source of calcium. ${ }^{8}$ By prescribing increased amounts of calcium and phosphorus only when the fluid and amino acid intakes were appropriate, precipitation was avoided. The increased plasma phosphate concentrations in group 2 suggest that the increased mineral content is retained with the higher formulation. ${ }^{10}$

Plasma alkaline phosphatase activity is a clinically practical screening test for significant demineralisation $^{13}$; biochemical rickets frequently precedes the typical radiological changes. Occasionally the alkaline phosphatase activity is in the normal range even in radiologically apparent rickets. ${ }^{14}$ Photon absorptiometry provides an accurate quantification of demineralisation, ${ }^{15}$ but this method was not available to us. The radiological scoring system developed by Koo et al does, however, also permit an objective grading of osteopenia (to rickets) as well as comparison between infants, and is particularly useful in the diagnosis and subsequent monitoring of progress to healing. ${ }^{11}$

The lower plasma alkaline phosphatase activity and better radiological outcome in group 2 suggests that overall bony mineralisation was improved compared with the group that received less mineral supplement. This outcome cannot be explained by differences in intake of other minerals, such as copper and zinc, as there was no difference in these between the groups.

Our results indicate that it is possible to increase the calcium and phosphorus content of intravenous feeding solutions significantly to match more accurately the intrauterine accretion rates, and that this reduces the incidence and severity of metabolic bone disease in preterm infants who require this form of nutrition. Metabolic bone disease can exacerbate bronchopulmonary dysplasia ${ }^{16}$ as well as cause respiratory problems in preterm infants with no other identifiable lung disease. ${ }^{17}$ Muscle weakness secondary to phosphorus depletion may also cause additional complications. ${ }^{18}$ Improved skeletal mineralisation should therefore help to alleviate the chronic respiratory problems that are common in these infants.

We thank the junior doctors and nursing staff of the neonatal intensive care unit for their help, and Dr K MacRae for statistical advice.

\section{References}

1 McIntosh N, Livesey A, Brooke OG. Plasma 25-hydroxy vitamin D and rickets in infants of extremely low birthweight. Arch Dis Child 1982;57:848-50.

2 The TS, Kollee LAA, Boon JM, Monrents LAA. Rickets in a preterm infant during intravenous alimentation. Acta Paediatr Scand 1983;72:769-71.

${ }^{3}$ Brooke OG, Lucas A. Metabolic bone disease in preterm infants. Arch Dis Child 1985;60:682-5.

${ }^{4}$ McIntosh N, De Curtis M, Williams J. Failure of mineral supplementation to reduce incidence of rickets in very-lowbirthweight infants. Lancet 1986;ii:981-2.

${ }^{5}$ Greer FR, Tsang RC. Calcium, phosphorus, magnesium and vitamin $\mathrm{D}$ requirements for the preterm infant. In: Tsang $\mathrm{RC}$, ed. Vitamin and mineral requirements in the preterm infant. Ncw York: Marcel Dekker, 1985:99-136.

${ }^{6}$ Poole RL, Rupp CA, Kerner JA. Calcium and phosphorus in neonatal parenteral nutrition solutions. Journal of Parenteral and Enteral Nutrition 1983;7:358-60.

${ }^{7}$ Knight PJ, Buchanan S, Clatworthy HW Jr. Calcium and phosphate requirements of preterm infants who requirc prolonged hyperalimentation. JAMA 1980;243:1244-6.

${ }^{8}$ Niemiec PW Jr, Vanderveen TW. Compatability considerations in parenteral nutrient solutions. Am J Hosp Pharm 1984;41: 893-911.

${ }^{9}$ MacMahon P. Prescribing and formulating neonatal intravenous feeding solutions by microcomputer. Arch Dis Child 1984;59: 548-52.

${ }^{10}$ Lyon AJ, McIntosh N. Calcium and phosphorus balance in extremely low birthweight infants in the first six weeks of life. Arch Dis Child 1984;59:1145-50.

$"$ Koo WWK, Gupta JM, Nayanar VV, Wilkinson M, Posen S. Skeletal changes in preterm infants. Arch Dis Child 1982;57: 447-52.

12 Ricour C, Millot M, Balsam S. Phosphorus depletion in children in long term parenteral nutrition. Acta Paediatr Scand 1975;64: 385.

13 Kovar IZ, Mayne P, Barltrop D. Plasma alkaline phosphatase activity: a screening test for rickets in preterm neonates. Lancet 1982;i:308-10.

${ }_{14}$ McIntosh N. Rickets of prematurity. Bone 1984;1:26-7.

is Cameron JR, Mazess RB, Sorenson JA. Precision and accuracy 
of bone mineral determination by direct photon absorptiometry. Invest Radiol 1968;3:141-5.

16 Geggel RL, Pereira GR, Spackman TJ. Fractured ribs: unusual presentation of rickets in premature infants. $J$ Pediatr 1978;93: 680-2.

17 Glasgow JFT, Thomas PS. Rachitic respiratory distress in small premature infants. Arch Dis Child 1977;52:268-74. ${ }^{18}$ Schott GD, Wills MR. Muscle weakness in ostcomalacia. Lancet
1976;i:626.

Correspondence to Dr IZ Kovar, Department of Paediatrics, Charing Cross Hospital, Fulham Palace Road, London W6 8RF.

Accepted 24 October 1988

\section{Perinatal lessons from the past}

'Is there anything whereof it may be said, See, this is new?

It hath been already of old time, Which was before us'

Ecclesiasticus, 1, 10

In 1963 the late Professor A V Neale of Bristol read to us from William Smellie's famous Midwifery (1752) during a ward round. For me this was the start of a voyage of excitement and delight into medical history. It is in the hope that others will be stimulated to share this pleasure that the Editors agreed to my preparing a series of articles of which the first concerns James Blundell and neonatal resuscitation ( $p$ 494). My purpose will not be confined to illustrating the accuracy of the quotation from Ecclesiasticus shown above. I hope also from time to time to reveal the truth of a remark made by Sir Robert Hutchison during his Harveian Oration in the Royal College of Physicians in 1931:

'Look round this room in which we are met. It is a noble library indeed, but is it not also a mausoleum? And how many facts which men are at present hunting for, and theories which are even now being put forward as new, lie already buried in these shelves'.

The importance of a knowledge of medical history is also clearly drawn in the following lines written in 1925 by that wise paediatrician, historian, and philosopher, Dr John Ruhräh of Baltimore:

'The unread physician is like a man in the theater without a program or a libretto or often, perhaps, without even a knowledge of the language of the stage. He is like a deaf man at an opera. Someone who has been watching the play before he came in may tell him something about it; who the principal characters are; who it is that sings so sweetly, so convincingly. He may gain a slender knowledge of the plot from what the actors say or do, and that is all. The jester enters, makes a loud noise with an empty bladder on the end of a stick, tweaks the nose of the king or his chancellor, cracks his timehonored jest and vanishes amid the laughter and applause of the delighted, if uninitiated, audience. Character after character appears and disappears, most of them the same old familiar faces, though sometimes with new names and new costumes. The auditor gasps and wonders. A timid voice speaks a great truth, but no one pays attention and presently the stage manager pulls the speaker from the stage while the clown and the trained dogs hold the attention of the audience.

A century or two later, the same truth is told again, but now the spotlight is on the handsome actor, with a wonderful voice, mouthing his nothings most delightfully. Again the audience pays no attention, but after many repetitions, the stage is set for Truth and, amid great applause, some one or a group parade Her with great pomp, as if for the first time. The audience gasps again and asks why She was not brought out before: so wonderful She is! Had he but known, had he paid attention-he had heard it long ago, but Now it is the wonderful, new thing. But perhaps it was not on the stage while he was in the audience. Well, it was set down in the account of the play, but he was too indolent, too busy, or else too lazy to read it.'

P M DunN 